\title{
Computerisation of Public Administration in Slovakia - Impact on (the Fiscal Position of) Municipalities $^{1}$
}

\author{
Anna Románová, ${ }^{*}$ Karolína Červená**
}

* JUDr. Anna Románová, PhD, is a researcher at the Pavol Jozef Šafárik University in Košice, Faculty of Law. Her specialisations are direct taxation, local taxes and tax administration. She is the author of more than 50 reviewed scientific outputs in the form of articles in journals, chapters in monographs and conference papers. She is a member of the International Property Tax Institute, Toronto, and the Centre of Information and Organization of Public Finances and Tax Law Research in Central and Eastern Europe. (e-mail: anna.romanova@upjs.sk)

** Ing. Karolína Červená, $\mathrm{PhD}$, is a teacher at the Pavol Jozef Šafárik University in Košice, Faculty of Law. Within her research and teaching activities, she pays special attention to assorted microand macroeconomic issues from an interdisciplinary perspective. She is the author of more than 80 reviewed scientific outputs in the form of articles in journals, chapters in monographs, conference papers. She is a member of the Centre of Information and Organization of Public Finances and Tax Law Research in Central and Eastern Europe. (e-mail: karolina.cervena@upjs.sk)

\begin{abstract}
The authors of the paper will analyse the structure of revenues and expenditures of local governments and evaluate the actual level of their independence. The authors will try to identify the room for improving of the financial position of the municipalities and special attention will be paid to a certain means of rationalisation of public administration, particularly computerisation within the e-Government projects that should, inter alia, lead to reduction of the administrative burden laid upon (local) government bodies and also saving of the budget. The analysis, largely based on a survey conducted by the authors within primary research, shows that performance of reforms in terms of rationalisation efforts may be a way forward, hence, the one analysed in this paper was not implemented in a fully satisfactory manner.
\end{abstract}

Keywords: municipality; self-government; computerisation; rationalisation; e-Government; local tax

\section{Introduction}

The process of fiscal decentralisation in the Slovak Republic started in $2005,{ }^{2}$ though there are various opinions on the current level of decentralisation in the Slovak Republic as such. ${ }^{3}$ The Constitutional Act No. 460/1992 Coll., Constitution of the Slovak Republic (hereinafter referred to as "Constitution") designates the municipalities and higher territorial units (hereinafter referred to as "HTU") as the basis of self-government in its Article 64. Due to the limited scope of this paper, the authors will only deal with municipal ${ }^{4}$ finances and leave aside the situation of the HTUs. Municipalities are responsible for the 
performance of self-governing functions as well as transferred State administration. For this purpose, the structure of their budgetary revenues consists of two source types, i.e. those acquired within their own authority (based on a special law) in terms of fiscal decentralisation and those transferred by the State. Article 65 of the Constitution declares that municipalities and HTUs shall fund their needs predominantly with the use of their own revenues, and subsequently from State grants. Although they are allowed to earn their own revenues (e.g. through local taxes), the financial situation of municipalities is generally perceived as under-funded.

The complex aim of this paper is to evaluate the current state of funding of municipalities in Slovakia. In this context, the authors therefore analyse the composition and significance of particular municipal revenue sources to evaluate the fiscal position of municipalities and aim to identify the room for possible improvement (targeted at the possible use of the potential of the real property tax). Subsequently, the research task will be the assessment of one particular recent measure of rationalisation of public administration, namely the computerisation of public administration, following the previous research of the authors. ${ }^{5}$ Based on the results of their own empirical research, the authors' aim will be the critical assessment of the outcomes of implementation of this measure in view of confirming or reputing the benefits of the measure for the municipalities from the viewpoint of improving their fiscal position (especially by administrative and/or financial efficiency).

The authors used standard methods of scientific research, namely: analysis, deduction, induction and synthesis. The paper contains the presentation of the results of the survey that was carried out from October 2016 to December 2017 on the research sample consisting of all the municipalities in the Slovak Republic $(2,927)$ and their employees (according to availability of information on municipal employees). The number of responses received as regards the municipalities was 830 and 2,909 as regards their employees. The individual segments of the research sample were sorted out by size (municipalities by population density unit of 500 inhabitants); cities and city districts were treated separately. In the processing and evaluation of the collected primary and secondary data, the authors used standard statistical methods of descriptive statistics. The outcomes are presented in graphical and tabular forms.

\section{Fiscal Position and Budgets of Municipalities}

The actual sources of municipal revenues are defined by Act No. 369/1990 Coll. on Municipalities as amended (hereinafter referred to as "Act on Municipalities") and Act No. 583/2004 Coll. on Fiscal Rules of Local Self-governments and on the change of and amendments to certain acts (hereinafter referred to as "Act on Fiscal Rules") setting forth that revenues of the budgets of municipalities consist of their own and other resources. ${ }^{6}$ Other important acts include Act No. 564/2004 Coll. on Budgetary Determination of Income Tax Revenue for Local Self-governments and amending certain acts as amended (hereinafter referred to as "Act on Budgetary Determination of Income Tax"), Act No. 582/2004 Coll. on Local Taxes and Local Charge for Municipal Waste and Minor 
Construction Waste as amended (hereinafter referred to as "Act on Local Taxes"), and Act No. 447/2015 Coll. on Local Charge for the Development and on amendment to certain acts (hereinafter referred to as "Act on Local Charge").

Own resources as defined by the Act on Fiscal Rules are created by:

- revenues from local taxes - these are based on Act on Local Taxes which entitles the municipalities to impose real property tax, dog tax, tax on the use of public areas, accommodation tax, vending machines tax, non-winning gaming machines tax, tax on the use of public areas, tax on entry and stay of motor vehicles in historical parts of towns and nuclear facility tax. They are fully administered by the municipalities and the taxes are actually imposed by municipalities by means of generally binding regulations (hereinafter referred to as "GBR"). Within these, municipalities are allowed to adjust tax rates, value of civil construction plots, floor surcharge, additional reliefs, instalments, reporting duties and the data to be reported to the tax administrator, etc., which enables them to regulate local taxation according to their local needs. Among local taxes, the most important own tax resource is the real property tax. The property tax is three-tier and is levied on a) lands, b) buildings, and c) flats and non-residential premises;

- revenues from local charges - there are two of them, firstly, the local charge for municipal waste and small construction waste (hereinafter referred to as "charge for municipal waste") regulated by the Act on Local Taxes and, secondly, the local charge for development (hereinafter referred to as "charge for development") governed by the Act on Local Charge, the latter being levied upon constructions on land ${ }^{7}$ within the territory of the municipality for which valid building permissions are issued; ${ }^{8}$

- non-tax revenues from the ownership of municipal property (including its transfer) and activities of the municipality and its budgetary organizations;

- interest and other revenues from the funds of the municipality;

- sanctions for violations of financial discipline imposed by the municipality;

- donations and revenues from voluntary collections to the municipality;

- the share of the taxes administered by the State - based on the Act on Budgetary Determination of Income Tax, the revenue from the income tax to be transferred to municipal budgets is in the amount of $70.0 \%$ and to budgets of HTUs in the amount of $30.0 \%$. The sums are distributed to particular municipalities and the HTUs pursuant to specific criteria defined by the Government Regulation No. 668/2004 Coll. on the Distribution of Personal Income Tax Revenue to Local Selfgovernments (comprising the data on the number and structure of residents, the area and other coefficients); and

- other revenues on the condition that a special law provides so expressly. A municipality is also allowed to use extra-budgetary monetary funds, funds obtained from their own business activities, refundable sources of financing, and joint financial resources. 
The others include:

- subsidies from the State budget covering the costs of the transferred performance of the State administration and subsidies from State funds (granted following the details of the State budget for a particular budget year from the budget chapters of the particular ministries, e.g. the Ministry of the Interior regarding the operation of the registry offices, reporting of residence of citizens, and the operation of the Registry of Inhabitants of the Slovak Republic, the elections, funding of regional education, etc.);

- additional subsidies from the State budget - these cover usually the issues like housing development, support of territorial development, etc.;

- purpose-built subsidies from the HTUs or from the budget of another municipality to carry out contracts under special acts (municipalities may, under Article 7 para. 2 of the Act on Fiscal Rules, provide grants to another municipality or the HTU, if they secure certain tasks for the municipality or for assistance in liquidation of consequences of natural disasters, accidents or other similar events in their area; they also may establish joint extra-budgetary cash funds for funding of the tasks common to more municipalities or for any other reason, i.e. cooperation between municipalities ${ }^{9}$ - the most common is the joint exercise of responsibilities in the area of technical infrastructure, administration, applying for grants from the European funds for development projects, or others);

- funds from the European Union and other foreign funds granted for a specific purpose; and

- other revenues.

The difference between own and other revenues consists in the fact that the own resources (except for purpose-built donations) may be used by a municipality according to its needs upon its decision, while the others have to be used only for a specified purpose (as is the case of funds transferred for the performance of the transferred State administration). This division may, however, be illogical in some way due to the inclusion of shared taxes into own municipal revenues when these clearly do not truly have a nature of own resources. We assume that this "helps" improve the proportion between own and other municipal revenue sources in favour of the former, albeit just formally.

The above revenues are used for covering the expenditures as defined by the Act on Fiscal Rules, which, in our view, are quite standard, such as: obligations of the municipality resulting from the special regulations; performance of self-governing powers of the municipality and for the activity of budgetary organizations and contributory organizations established by the municipality; transferred State administration; administration, maintenance, and valorisation of the municipal property and the other property used to perform municipal tasks; obligations arising out of cooperation with another municipality or with an HTU or with other persons to ensure the tasks arising from the municipality's competence; duties arising from international cooperation of the municipality; interest on borrowings, loans and repayable financial assistance; expenditure related to the issuance of securities issued by the municipality and the expenses for reimbursement of the returns thereof; and other expenditure provided for by special regulations. ${ }^{10}$ 


\subsection{Actual revenues structure}

To provide the reader with the view of the actual significance of the above kinds of revenues, Figure 1 and Figure 2 show the shares of particular revenue types comparing the years 2016 (the most recent data available) and the year 2008. These show that there are only negligible differences in the development of the ratios of various revenues and that the current state is rather stable. ${ }^{11}$

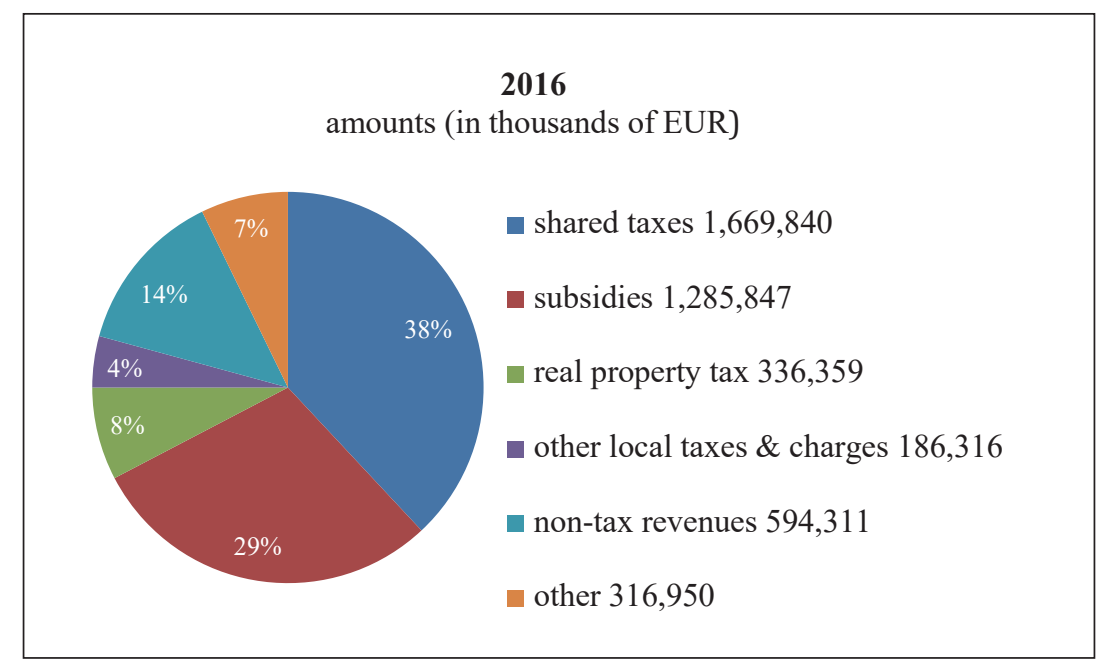

Figure 1.

Municipal revenues structure (2016)

Source: Ministry of Finance of the Slovak Republic. Public administration budget, www.finance. gov.sk/sk/financie/verejne-financie/rozpocet-verejnej-spravy/ 


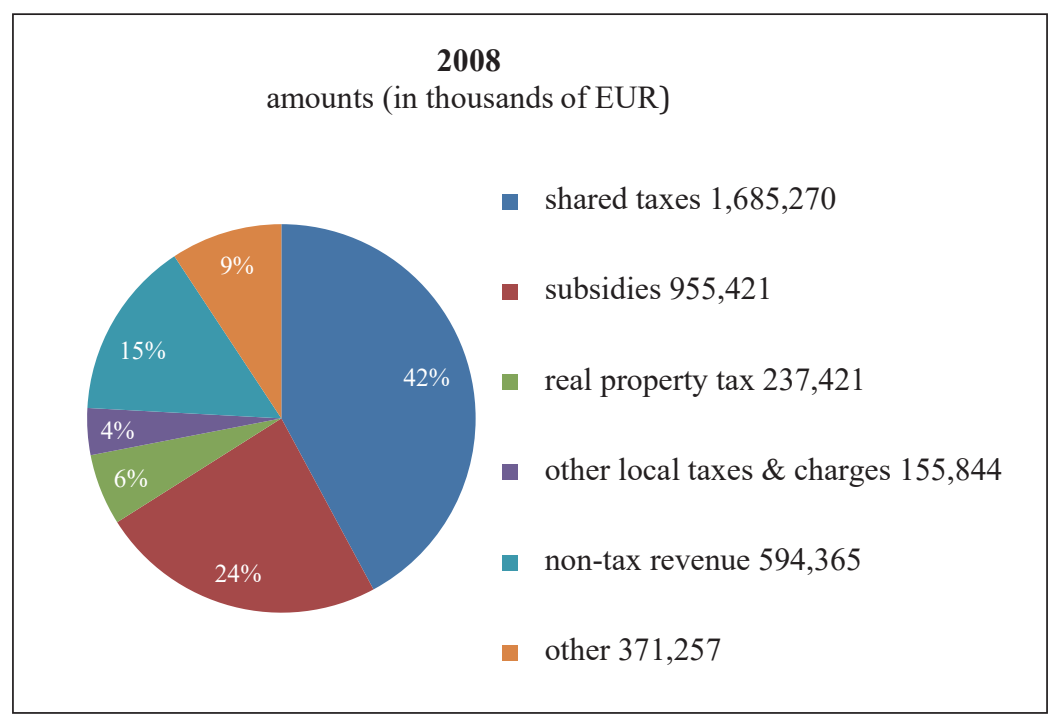

Figure 2.

Municipal revenues structure (2008)

Source: Ministry of Finance of the Slovak Republic. Public administration budget, www.finance. gov.sk/sk/financie/verejne-financie/rozpocet-verejnej-spravy/

The situation as seen from the figures above was set after the major tax reform in $2004^{12}$ which entitled the municipalities to impose local taxes and determine, i.a. the majority of applicable tax rates. ${ }^{13}$ The fact that municipalities were granted a right to set the tax rates according to their needs, even - as in case of real property tax - different for various municipal areas/zones and types of properties or the use thereof, changed their position in regard of the ability to influence the amount of received tax revenues and this right was vastly exercised, as is seen from Figure 3. 


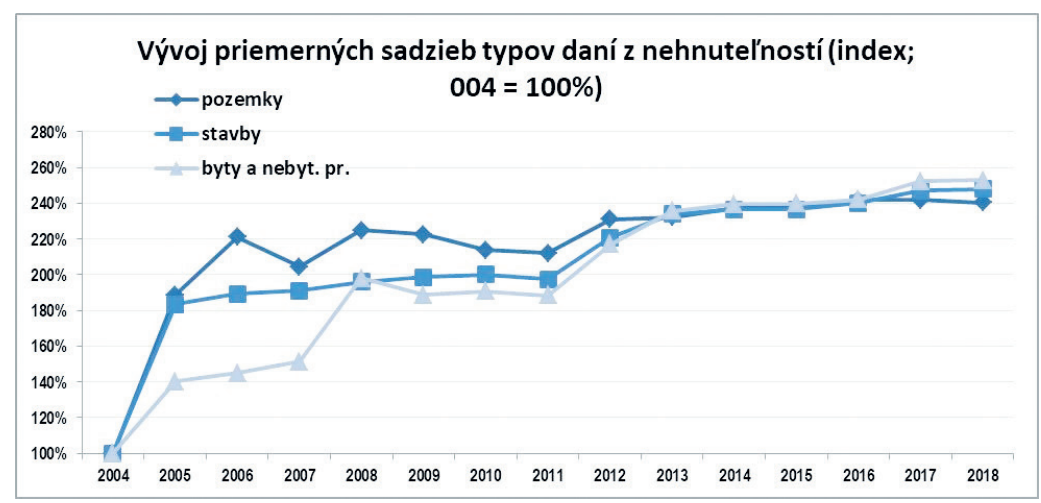

Figure 3.

The development of average real property tax rates from 2004 to 2018

Source: Podnikatel'ská Aliancia Slovenska, alianciapas.sk/dane-z-nehnutelnosti-sa-tento-roktakmer-nepohli-vynimkou-je-myjava-mesta-poplatok-za-miestny-rozvoj-takmer-nevyuzivaju/

\section{In Search of Measures to Improve the Fiscal Situation and Promote a Greater Efficiency}

As Figure 3 confirms, the total revenues of municipalities at the time of implementation of the reform were insufficient and there was a strong need to raise more revenue. In the current situation, we can assess that some elements of the then situation are still present and some of them have improved. The proportion of particular types of revenues have stabilised, but there is still a need for improving the financial situation of municipalities, which are highly dependent on not truly own resources, as was seen in Figures 1 and 2. Raising the real property tax rates by municipalities is no longer an effective tool to acquire more revenue, as we can see from the horizontal curve in Figure 3 in the last 4 or 5 years. ${ }^{14}$ The main reason is not the lack of potential of the real property tax (as is demonstrated by comparisons in Table 1), but the lack of political will caused by total unacceptance of the real property tax reform by the public. ${ }^{15}$ Although the idea of a reform was included in the National Programme of Reforms in the SR in 2016 as a task of the Government in coordination with the Association of Towns and Municipalities of Slovakia to "create the technical conditions for a change of the system of the real property taxation towards determining the tax base by the property value in order to increase tax fairness and efficiency concerning local taxes" and also in the Government Statement for the years 2016-2020, the future of the eventual reform stays uncertain. ${ }^{16}$ Should the reform be satisfactorily implemented, it might be a welcome solution to the financial (and other related) problems of local governments. ${ }^{17}$ 
Table 1.

Real property tax performance comparison

\begin{tabular}{|l|c|c|c|}
\hline \multicolumn{1}{|c|}{ Country/RPT } & $\%$ GDP & $\%$ Total Taxes & \% Local government revenues \\
\hline Moldova & $0.1 \%(2013)$ & $0.3 \%(2013)$ & $7.6 \%(2013)$ \\
\hline $\begin{array}{l}\text { The Czech } \\
\text { Republic }\end{array}$ & $0.2 \%(2015)$ & $0.6 \%(2015)$ & $1.4 \%(2012)$ \\
\hline Estonia & $0.3 \%(2014)$ & $0.9 \%(2014)$ & $6.8 \%(2014)$ \\
\hline Lithuania & $0.3 \%(2013)$ & $1.7 \%(2016)$ & $8.2 \%(2016)$ \\
\hline Slovakia & $0.4 \%(2016)$ & $2.9 \%(2016)$ & NA \\
\hline Hungary & $0.6 \%(2014)$ & $1.6 \%(2014)$ & $\mathbf{1 0 . 6 \% ( 2 0 1 5 )}$ \\
\hline Slovenia & $\mathbf{0 . 6 \% ( 2 0 1 5 )}$ & $\mathbf{1 . 7 \% ( 2 0 1 5 )}$ & $9.0 \%(2014)$ \\
\hline Latvia & $0.8 \%(2015)$ & $2.8 \%(2015)$ & $14.3 \%(2015)$ \\
\hline Bulgaria & NA & $1.6 \%(2015)$ & $9.0 \%(2015)$ \\
\hline Romania & $0.8 \%(2015)$ & $4.0 \%(2015)$ & $5.3 \%(2015)$ \\
\hline Ukraine & $0.8 \%(2015)$ & $3.1 \%(2015)$ & $22.0 \%(2016)$ \\
\hline Poland & $1.2 \%(2016)$ & $3.9 \%(2013)$ & $6.0 \%(2015)$ \\
\hline Russia & $1.1 \%(2015)$ & $13.6 \%(2015)$ & NA \\
\hline USA & $2.6 \%(2014)$ & $9.9 \%(2014)$ & NA \\
\hline Canada & $2.7 \%(2014)$ & $8.7 \%(2014)$ & $\mathbf{3 A} \%$ \\
\hline OECD av. & $\mathbf{1 . 1 \% ( 2 0 1 3 )}$ & $3.3 \%(2013)$ & \\
\hline
\end{tabular}

Source: Iptipedia and country presentations presented at the Market Value-based Taxation of Real Property: Lessons from International experience. Lincoln Institute of Land Policy \& Center of Excellence in Finance, Ljubljana, Slovenia, 23-27 March 2015, 16-20 May 2016 and 06-10 March 2017.

This situation leads municipalities to permanent dependence on the State transferred revenues (shared personal income tax income and grants and transfers). This, together with the statutory necessity of a surplus or at least a balanced budget, causes that the municipalities that are unable to gain funding in any other way (e.g. from the disposal of municipal property or by using specific grants or loans) simply do not invest into development of their municipality. Other revenue sources need to be sought. ${ }^{18}$ This problem may be addressed partially by a rather new tool - the charge for development, the use of revenue thereof is purpose-built - its revenue may only be used to cover capital expenditures related to constructions (including the settlement of land) to be used as childcare facilities; facilities providing social, sporting and cultural services; social housing; school equipment and devices for practical training; medical equipment; a publicly accessible park or adjustment of the public green; local roads, parking areas and technical infrastructure. We are, however, unable to estimate its fiscal effect, as there are no available data due to its only recent implementation, nevertheless, the first news show quite a low interest of the municipalities. ${ }^{19}$ 
One of the reasons for criticism of decentralisation in the Slovak Republic is still a large level of bureaucracy and lack of systemisation of public administration, and the municipal level is not an exception. Within the decentralisation of public administration, a large number of duties and responsibilities were transferred to municipal levels, which as such is a good position in respect of the proportionality principle, on the other hand, in many cases, this competence transfer was followed neither by sufficient technical equipment nor by adequate administrative staffing. ${ }^{20}$ This is connected to a specific phenomenon of enormously large number of municipalities, which can be found also e.g. in the Czech Republic $^{21}$ and more examples can be found. ${ }^{22}$ As of the state of the last census in Slovakia in the year 2011, ${ }^{23}$ there are 2,927 cities, city districts, and municipalities. In addition to 140 municipalities with the status of cities, 1,919 out of 2,751 municipalities have less than 1,000 inhabitants and still are obliged to fulfil the duties of the public administration authority, which is subject to frequent criticism. ${ }^{24}$ The two largest cities in Slovakia, Bratislava and Košice, are divided into city districts, where Bratislava with its 411,228 citizens is divided into 17 city districts and Košice with its population of 240,433 into even more - 22 city districts. All of the city districts serve the administrative purposes as partially independent municipalities with their local governments, administration and bureaucratic apparatus. These huge numbers of separate administrative units are, in our opinion, one of the reasons why the municipal revenues cannot be used as efficiently as they would be, should the bureaucracy be cut and not duplicated under the current situation. We understand that the cost-driven approach cannot be the principal reason for consolidation of municipalities, nevertheless, the growth of efficiency has been proved. ${ }^{25}$ As Sopkuliak concludes, the smallest municipalities have a very high share of expenditures spent on general public services (connected to personal and technical running costs) per citizen as compared to larger municipalities and therefore consolidation of local selfgovernments should improve their ability to save their revenues and use them for other developing activities. ${ }^{26}$ One of the measures to enable mainly the small municipalities to "join the forces" under the current legislation is the possibility to run joint municipal offices, which is quite used, especially for special purposes of the transferred State administration, e.g. joint building offices.

One of the most recent reforms aiming at rationalisation of public administration is the digitalisation of public administration. Figure 4 shows the overall current use of e-agenda and e-services at the local level. At the mentioned local level, there have been various projects and grants to fund the implementation of digitalisation of municipal and city administration. 


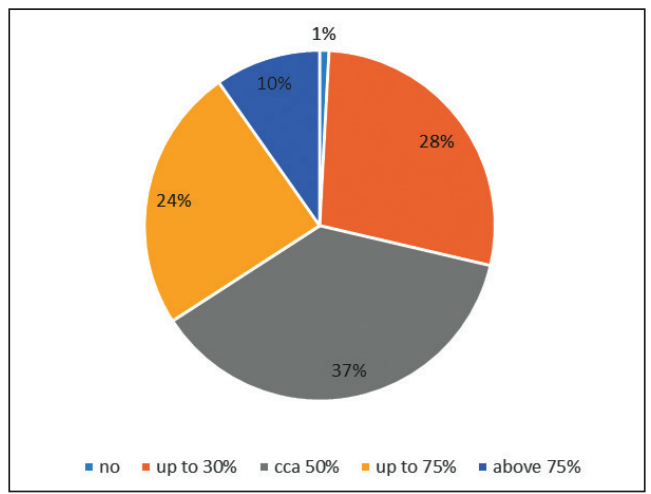

Figure 4.

Share of the use of e-agenda on the municipal level

Source: Drawn by the authors on the basis of the results of the survey conducted by the authors.

A recently implemented DCOM project (Data Centre of Computerization of Local Selfgovernments of Slovakia) provided the support to Slovak towns and municipalities with the necessary software to perform the e-Government functions and processes. The overall use of the DCOM support has been declared by $79.72 \%$ of survey responding towns/ municipalities; the rest of them use different e-Government performance enabling software tools.

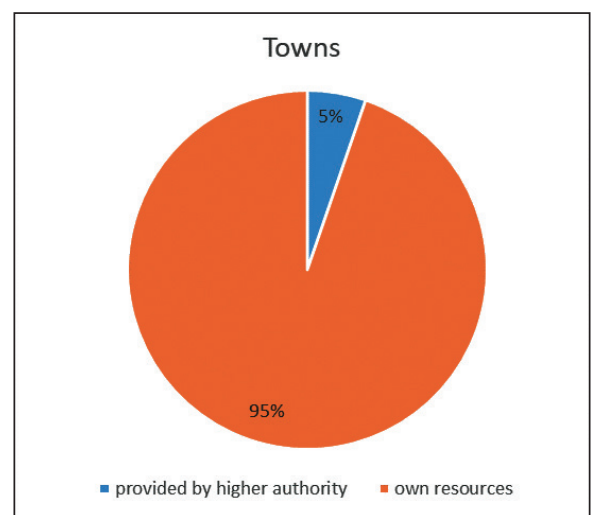

Figure 5.

Funding of software (58 towns - 57 responses)

Source: Drawn by the authors on the basis of the results of the survey conducted by the authors. 


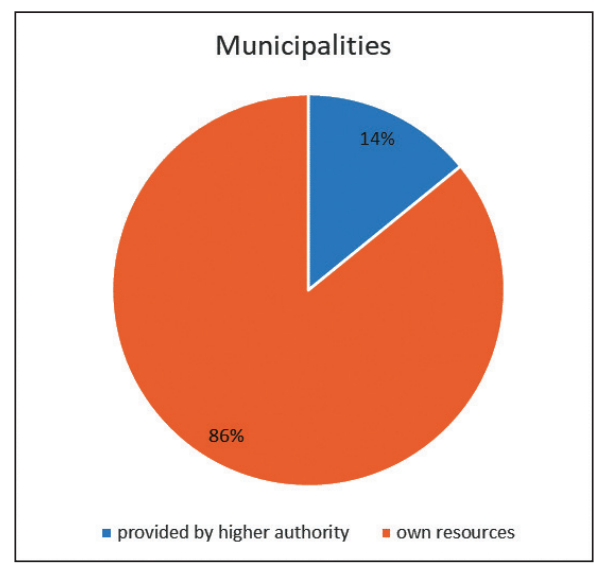

Figure 6.

Funding of software (769 municipalities - 758 responses)

Source: Drawn by the authors on the basis of the results of the survey conducted by the authors.

Figures 5 and 6 show the ratio between the towns and municipalities that have been provided with the necessary software by a superior authority and those which secured it from their own resources. $86.52 \%$ of municipalities/towns have acquired the software for electronic administration and data procession from their own resources, while only $13.48 \%$ of them have been provided therewith by the superior authorities. Material and technical equipment (as a prerequisite for the actual provision of e-services) is primarily obtained by the municipalities themselves, which, in our opinion, is the main reason why some municipalities still do not provide e-services at all or only to a limited extent and/or in a low quality. Under the current regulation (Act No. 305/2013 Coll., Act on e-Government), as of 1 November 2016, all the municipalities should have provided the services of public administration electronically. Based on this fact, it seems rather surprising that the services of receipt and delivery of electronic documents (within the e-Government performance) have reached very low shares (only $24.72 \%$ municipalities declared to deliver their decisions electronically, 22.68\% use communication signed by qualified electronic signatures within communication with other public authorities) compared to other e-services, e.g. e-mail or electronic formularies that are used vastly (e.g. internal e-mail communication $81.07 \%$, e-mail communication with other authorities $99.76 \%$; with businesses $74.08 \%$, with citizens $67.96 \%$; use of electronic formularies $53.62 \%$ ).

The contractual price for the provision and service of the DCOM information system has been set at EUR 62,844,76.34, which together with other projects (the total expenses of those projects are unavailable, since the Slovak Government was, to our surprise!, unable to answer our request for this information) might be quite a high sum. Despite that, altogether with the common-unified web service for electronic communication with public administration (www.slovensko.sk) is not unproblematic. 


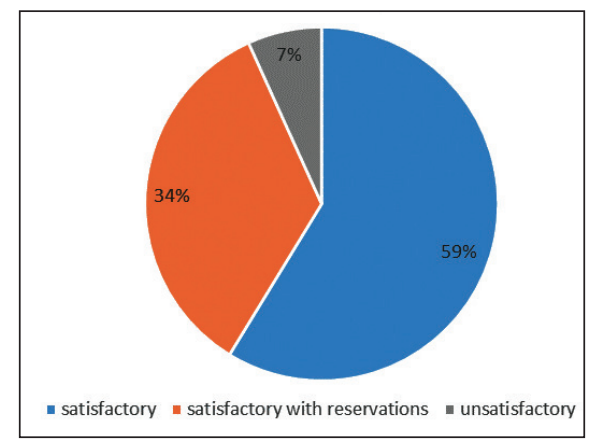

Figure 7.

Overall satisfaction of municipalities with functioning and user comfort of e-services/e-agenda (795 responses)

Source: Drawn by the authors on the basis of the results of the survey conducted by the authors.

Following Figure 7, 59\% of the respondents are satisfied with the functioning and comfort level of the current e-Government processes, while 34\% are satisfied only partially and $7 \%$ are dissatisfied. Most negative responses were regarding the functioning of the qualified electronic signature communication where $58.68 \%$ of its users declared dissatisfaction with the user comfort, however, considered it to be rather efficient (cost and/or time saving) - with $84.82 \%$ of the users. Within the survey, various objections and remarks regarding the overall assessment of the e-Government functioning were raised by the respondents. We learnt from more than 323 remarks of municipal/city representatives that the most significant defects of the current state are a) malfunctions or incompleteness of the system and technical defects with 77 objections; b) lack of transparency of the system and poor user comfort (including complicated work with the system, unclarity for ordinary users, opaque websites and incompleteness of the data) with 69 objections; c) low level of comprehensiveness and integration/interconnection of the systems and registers administered by the authority itself and with other public administration authorities within various agenda causing duplicity and lack of interoperability with 38 objections together with 11 responses on duplicity of work caused by the need to deal with "paper" agenda, files or communication alongside with the electronic ones. 26 respondents claimed lack of good standard of the Internet connection. 25 respondents depicted low level of adequate technical equipment and qualified staff or financial resources and 27 presented dissatisfaction with a small number and/or poor quality of trainings for the employees; 20 remarks were aimed at unpreparedness, slow implementation, and unsystematic approach within the process of e-Government and 13 claimed their opinion on raise of bureaucracy. 11 respondents claimed low interest or unawareness of the clients/addressees, especially in smaller municipalities and as regards older citizens or persons without adequate technical skills and 6 pointed out low level of awareness. The rest of the remarks were of a general nature or unidentifiable. 
As regards the view of respondents on the efficiency of e-services, the majority of them are in favour thereof, as is clear from Figure 8 which also corresponds to the overall preference of the e-service use (Figure 9). A different situation was found concerning the efficiency of communication with qualified electronic signature (which is the substantial part of e-Government), where only $17.94 \%$ of the respondents declared time-saving (12.38\% declared as not cost-saving and $69.68 \%$ were unable to assess it) and similarly only $18.03 \%$ cost-saving (16.20\% declared as not cost-saving and as much as $65.77 \%$ were unable to assess it). Nevertheless, the extension of electronic processes/services currently available would be welcome by only $24.94 \%$ of them.

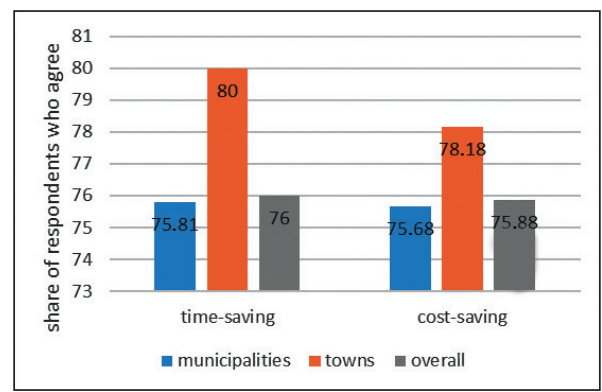

Figure 8.

Time and cost saving of e-services/e-processes ( 800 responses)

Source: Drawn by the authors on the basis of the results of the survey conducted by the authors.

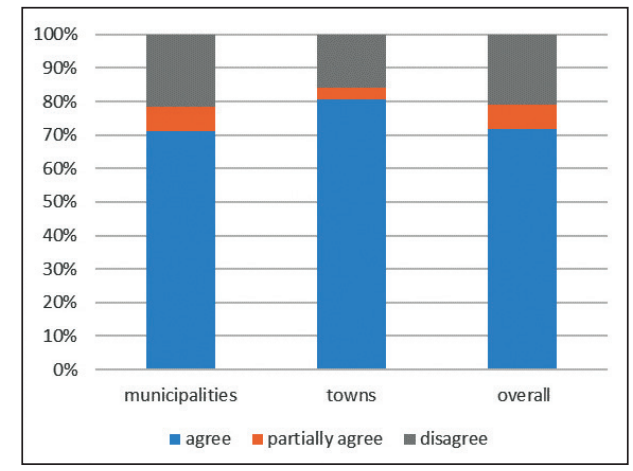

Figure 9.

Preference of e-services/software use over physical/paper form (812 responses)

Source: Drawn by the authors on the basis of the results of the survey conducted by the authors. 


\section{Conclusions}

Should we look at the primary goal of fiscal decentralisation, it definitely would be the creation of an independent self-government that is capable of funding its needs and execute its policy by its own resources. ${ }^{27}$ Slovakia truly started to fulfil this idea only after 2004 when local taxes as a true local revenue source were established. As we look at the current budgetary situation of the Slovak municipalities, one may conclude that there is still a high level of dependency on the State and its grants, transfers and shared state taxes (see Figure 1). Even though the shared taxes are statutory designated as own resource, the true own municipal resources do not represent a major revenue source. The real property tax as the most relevant own tax revenue has been criticised due to low revenue in the light of the GDP ratio ${ }^{28}$ (see Table 1), which is true, nevertheless, any potential real property tax changes are very sensitively addressed by the public which hinders any substantial or even minor changes in the current system. It is not only the mentioned low revenue, but also the unbalanced tax burden ${ }^{29}$ between taxation of businesses and households (which are strongly undertaxed), and there is also room for covering a larger scale of various property types (e.g. currently not taxed pipelines and constructions without roof or ceiling) or improving enforcement. ${ }^{30}$ Despite this, its system does have many positive features, such as the administrative simplicity, adjustability and high level of comprehensibility for the tax payers. Since the lack of political will or rather "know how" to "sell the reform", other means of improving, very often non-flattering, of the fiscal situation of municipalities have to be sought. We have mentioned a very lately introduced, now local charge for development. ${ }^{31}$ Nevertheless, there might also be room for more systematic changes, as the one analysed in the paper above - rationalisation tools. Letting alone the idea of limiting the number of municipalities, or at least their administrative apparatuses, which would be very welcome in the authors opinions, ${ }^{32}$ there might be another one - like the e-Government implementation - where one of the goals definitely is the efficiency increase. Such reforms might be very helpful for larger towns but also for small villages where they might counterbalance frequent understaffing and inadequate equipment. These, however, need to be implemented in a satisfactory way, should they improve the current situation. The results of the survey regarding the computerisation reform indicate ambiguous conclusions in this sense. There are many positive responses, however, a large number of problems and negative reactions were found. There has been a vivid discussion about the badly mastered computerisation reform in Slovakia due to various errors in the functioning of e-Government performance as such, not only at the municipal level..$^{33}$ We assume that the clients of the reform (citizens, employees of businesses and public authorities) did not receive a quality service for the "money spent" on the reform. A premature implementation of the reform without efficient technical service that is present in the reform at central state administration level is also found at the local level. Here, the problem might also lie with the fact that was mentioned above - a large number of small municipalities that are obliged to fulfil the tasks imposed by the legislation, in many cases without the necessary material, technical, personal or other equipment. The staff of such small municipal offices (not unusually less than 3 employees) ${ }^{34}$ is frequently not capable of handling the new (electronic) agenda due to lack of adequate education, training or large amount of other working tasks 
demanded due to understaffing. ${ }^{35}$ The problem is partially resolved by the existence of joint municipal offices, nevertheless, many tasks for such municipalities remain. It is therefore necessary to remember this fact within all the reformative processes within public administration in Slovakia. Following the results of the survey, we assume that as for small municipalities, imposing of duties as regards computerisation of public administration represents rather a burden than a tool for achieving a simpler and more efficient public administration. For this reason, we do think that this reform has not entirely fulfilled one of its goals - improving the efficiency - as regards the smaller municipal units. Should the reproached negatives be eliminated, the reform will definitely improve the efficiency of administrative tasks of municipalities in terms of both costs and time, as was already indicated by the evaluation within the survey. 


\section{References}

1 This chapter represents the partial output of the implementation of the APVV project No. 14-0598.

2 Phillip J. Bryson, Gary C. Cornia, Gloria E. Wheeler, Fiscal Decentralization in the Czech and Slovak Republics: A Comparative Study of Moral Hazard, 103-113, in Environment and Planning C: Politics and Space, vol. 22, no. 1 (2004). DOI: https://doi.org/10.1068/c0247; Eva Balážová, Viera Papcunová, Juraj Tej, Dopad fiškálnej decentralizácie na výnos z dane z nehnutel'ností na úrovni miestnej samosprávy SR [The Impact of the Fiscal Decentralisation on the Tax Revenue of Real Estate Tax on the Local Self-Government of the Slovak Republic], 891-898, in Victorie Klímová, Vladimír Žítek (eds.), XIX. mezinárodní kolokvium o regionálních védách. Sbornik príspèvkư $\left[19^{\text {th }}\right.$ International Colloquium on Regional Sciences. Conference Proceedings] (Brno, Masaryk University, 2016). DOI: https://doi.org/10.5817/CZ.MUNI.P210-82732016-115

3 Tamošiūnas states that Slovakia belongs to countries with a high level of decentralisation based on subsidies acquired - below 30\% (Teodoras Tamošiūnas, Valda Stanyté, Fiscal decentralisation in Lithuania in the context of EU countries, 157, in Scientific Papers of the University of Pardubice, Series D, Faculty of Economics and Administration, vol. 35, no. 3 [2015], 149-160, dspace.upce.cz/handle/10195/64708 [accessed 5 January 2018]), however, looking at Figure 1 later, we see that there is a large share of shared taxes, which are transferred by the central government. Based on the cost comparison method (share of the local governments' expenditures on public administration expenditures) with only $17 \%$ and the share of the local governments' expenditures on the GDP with only 6.3\% - compared to e.g. the Czech Republic - 10.2\%, Austria - 16.9\%, Hungary - 9.0\%, Poland $-13.4 \%$, Denmark $-37.6 \%$, Sweden $-25.7 \%$ (in 2012), domestic authors consider the level of decentralisation as rather low. The general perception is that the level is practically high due to many competences transferred to local governments. (Viktor Ňižňanský, Viera Cibáková, Marta Hamolová, Tretia etapa decentralizácie verejnej správy na Slovensku [The Third Phase of the Public Administration Decentralisation], 108 (Bratislava, Wolters Kluwer, 2014).

4 Since the legislative term "municipality" includes also municipalities with the status of cities or city districts (not only villages), we will follow the statutory terminology in this regard.

5 Anna Románová, Karolína Červená, Elektronická komunikácia podnikatel'ov $s$ verejnou správou (právne aspekty) [Electronic Communication of Entrepreneurs with Public Administration (Legal Aspects)], 865-875, in International Scientific Conference, Current Problems of the Corporate Sector 2016 (Bratislava, EKONÓM, 2016); Karolína Červená, Anna Románová, eGovernment ako prostriedok racionalizácie verejnej správy [e-Government as a Rationalisation Tool of Public Administration], 51-59, in Racionalizácia verejnej správy [Rationalisation of Public Administration] (Bratislava, Akadémia Policajného zboru v Bratislave, 2016).

6 Article 3 para. $1-3$ of the Act on Fiscal Rules.

7 Except for minor constructions, extensions and outbuildings up to 25 square meters of floor area, emergency construction works, family houses with a floor area of up to 150 square metres, constructions used for social housing or childcare, built-in garage and parking spaces within an existing building, medical facilities, serving to kindergartens or schools, social service facilities, practice of religion, protection of the State, museums, galleries, libraries and cultural centres.

8 For comparison see Michal Radvan, Taxes on Communal Waste in the Czech Republic, Poland and Slovakia, 511-520, Lex Localis - Journal of Local Self-Government, vol. 14, no. 3 (2016). DOI: https://doi. org/10.4335/14.3.511-520(2016)

9 Anna Kicová, Miroslav Štrkolec, Vzájomné finančno-právne vztahy jednotiek územnej samosprávy [Mutual Financial and Legal Relations among the Local Government Units], 381-391, in Finanse samorzadu terytorialnego [Local Self-government Finances] (Radom, Wyzsza Szkola Handlowa, 2012). 
10 For more see Andrej Sopkuliak, Štruktúra výdavkov miestnej samosprávy na slovensku v rokoch 2012-2014 [Expenditure Structure of Local Self-governments in Slovakia in 2012-2014], 774-780, in Victorie Klímová, Vladimír Žítek (eds.), XIX. mezinárodni kolokvium o regionálních védách. Sbornik prǐspèvkü [19 ${ }^{\text {th }}$ International Colloquium on Regional Sciences. Conference Proceedings] (Brno, Masaryk University, 2016). DOI: https://doi.org/10.5817/CZ.MUNI.P210-8273-2016-99

11 Compare: Miroslav Štrkolec, Príjmy miestnych daní - ústavné predpoklady a realita [Local Taxes Revenues Constitutional Preconditions and Reality], 338-343, in 15 rokov Ústavy Slovenskej republiky [15 Years of the Constitution of the Slovak Republic] (Košice, P. J. Šafárik University in Košice, 2008).

12 As part of fiscal decentralisation, Peter Molitoris, Legal Frameworks of Financing of Territorial Self-Government in the Slovak and Czech Republics, 229, in Slovenská a Česká republika po dvadsiatich rokoch [The Slovak and Czech Republics after Twenty Years] (Podhájska, Východoeurópska agentúra pre rozvoj, 2013), 224-236.

13 Michal Jesenko, Obec ako subjekt tvorby práva [Municipality as a Legislative Authority], 120 et seq. (Košice, P. J. Šafárik University in Košice, 2015).

14 And there are other reasons as well, see Peter Molitoris, Vlastné finančné zdroje územnej samosprávy a komunálna reforma [Own Financial Resources of Local Self-governments and Communal Reforms], 83, in Územná samospráva v procese decentralizácie verejnej správy [Territorial Self-Government in the Process of Decentralisation of Public Administration] (Košice, P. J. Šafárik University in Košice, 2010), 77-85.

15 Ibid. 81. This is also supported by mainstream media, e.g. Nový Čas: nezávisly dennik, www.cas.sk/ clanok/419746/mestski-poslanci-odklepli-zvysenie-dani-z-nehnutelnosti-za-byty-zaplatime-o-30-percentviac/; Denník Pravda, https://spravy.pravda.sk/ekonomika/clanok/433613-chysta-sa-absurdna-dan-z-podlazia/ (accessed 31 January 2018).

16 For more on the reasons and the situation see Anna Románová, Ivana Forraiová, Funding of municipalities in the Slovak Republic, related application problems and future challenges, 127-145, in Samorzad terytorialny w Polsce i w Europie. Aktualne problemy i wyzwania [Territorial Self-government in Poland and Europe. Current Problems and Challenges] (Wloclawek, Państwowa Wyższa Szkoła Zawodowa we Włocławku, 2017). DOI: http://dx.doi.org/10.21784/SamorzadTerytorialny.2017.010; or Mária Bujňáková, Anna Románová, Zamyslenie sa nad ideou zavedenia zdaňovania nehnutel'ností na princípe trhovej hodnoty [Thoughts about the Idea of Real Property Taxation Based on the Ad Valorem Principle], 61-75, in Právo, obchod, ekonomika IV [Law, Business, Economics IV] (Košice, Pavol Jozef Šafárik University in Košice, 2014).

17 Michal Radvan, The Draft Reform of Land Taxation in the Czech Republic, 229-245, in Lex Localis - Journal of Local Self-Government, vol. 10, no. 3 (2012). DOI: https://doi.org/10.4335/170; William J. McCluskey, Frances Plimmer, The Creation of Fiscal Space for the Property Tax: The Case of Central and Eastern Europe, 123-138, in International Journal of Strategic Property Management, vol. 15, no. 2 (2011). DOI: https:// doi.org/10.3846/1648715X.2011.582748

18 Petr Mrkývka, Damian Czudek, Fiscal Resources of Local Self-Government Budgets from Environmental Charges on Czech Republic, 669-683, in Lex Localis - Journal of Local Self-Government, vol. 15, no. 3 (2017). DOI: https://doi.org/10.4335/15.3.669-683(2017)

19 Podnikatel'ská Aliancia Slovenska: Real property taxes have hardly changed, except for Myjava. The charge for development is almost unused, http://alianciapas.sk/dane-z-nehnutelnosti-sa-tento-rok-takmer-nepohlivynimkou-je-myjava-mesta-poplatok-za-miestny-rozvoj-takmer-nevyuzivaju (accessed 31 January 2018).

20 Anna Románová, Karolína Červená, Implementation of e-Government in the Slovak Republic at the Level of Local Self-Government, 170-178, in Proceedings of the $17^{\text {th }}$ European Conference on Digital Government, (Reading, UK, Academic Conferences and Publishing International, 2017). https://doi.org/10.2139/ssrn.3781731

21 Radvan, supra n. 18, at 241. https://doi.org/10.4335/170

22 Marc Holzer, et al., Literature Review and Analysis Related to Municipal Government Consolidation (Newark, School of Public Affairs and Administration, SPAA, Rutgers University, 2009), nj.gov/dca/affiliates/luarcc/ pdf/final_consolidation_report.pdf (accessed 3 January 2018).

23 Towns of the Slovak Republic according to the number of inhabitants in 2011, sodbtn.sk/obce/statistika_obce. php (accessed 31 January 2018). 
24 e.g. Jozefína Machajová, Všeobecné správne právo [General Administrative Law], 149 (Bratislava, Paneuropean University, 2010); Balážová, supra n. 2, at 895.

25 Holzer, supra n. 23, at 7.

26 Sopkuliak, supra n. 10, at 779. https://doi.org/10.5817/CZ.MUNI.P210-8273-2016-99

27 Bryson, supra $n$. 2, at 113. https://doi.org/10.1068/c0247

28 Council Recommendation of 8 July 2014 on Slovakia's 2014 national reform programme and delivering a Council opinion on the Stability Programme of Slovakia, 2014 (2014/C 247/23).

29 McCluskey, supra n. 18. https://doi.org/10.3846/1648715X.2011.582748

30 We can find many examples of villages and cities where local taxes and charges are not duly collected (the local taxes and charges arrears amount, e.g. in the largest cities in Slovakia to: EUR 7,510,920.96 in Bratislava; EUR 4,887,964.48 in Košice; EUR 2,464,411.73 in Trenčín; EUR 4,992,097.73 in Nitra; EUR 3,439,441.16 in Žilina; EUR 3,862,743.99 in Banská Bystrica; EUR 1,069,501.00 in Prešov [ ${ }^{*}$ local charges not included]). Source: data provided by the cities upon the authors' request.

31 Adrián Popovič, Zamyslenie sa nad miestnym poplatkom za rozvoj [Few Thoughts about the Charge for Development], 1263-1276, Justičná revue, vol. 68, no. 11 (2016).

32 Similarly Ňižňanský, supra n. 3.

33 The authors experienced the functioning of electronic communication themselves and can confirm the ambiguous attitude based on a large number of technical complications and low awareness up to chaos regarding the duties and requirements within the communication. See also Karin Cakoci, Problémy so zavedením elektronického doručovania písomností [Problems Concerning the Implementation of Electronic Delivery of Documents], 67-71, in Vybrané instituty správy danív $\check{C} R$ a na Slovensku po novele [Assorted Institutes of Tax Administration in the Czech Republic and Slovakia after the Amendment] (Olomouc, Iuridicum Olomoucense, 2012).

34 The total of 572 municipalities out of 830 respondents declared to have 3 or less employees, not occasionally, including the mayor of the municipality.

35 Similarly Molitoris, supra n. 14, at 83. 